\title{
EPIDEMIOLOGICAL FEATURES OF LUMPY SKIN DISEASE OF THE LARGE RUMINANTS: REVIEW OF LITERATURE
}

\author{
Zeynalova Sh. K. \\ BSL-3 Central Reference Laboratory, Veterinary Scientific Research Institute, \\ Baku, Azerbaijan, e-mail: shzeynalova@mail.ru
}

\begin{abstract}
Summary. Lumpy skin disease (LSD) is an infectious disease in cattle, characterized by nodules on the surface of the skin and which can have serious economic consequences. Starting from 2014, new outbreaks of LSD in the world and its spread to Central Asia and the Middle East are noted. Due to the huge economic impact on the economy, the World Organisation for Animal Health (OIE) has classified LSD as a particularly dangerous disease that needs to be notified. The analysis of the literature on LSD shows that many issues remain unstudied and require appropriate research to be carried out. In connection with the difficult epizootic situation and the threat of further spread of the virus, the urgent task is the study of biological properties of the causative agent with a view of development the specific prophylactic agents that would allow to prevent the spread of infection in a short time
\end{abstract}

Keywords: Capripoxvirus, nodular dermatitis, Neethling virus, outbreaks, Azerbaijan

Introduction. Lumpy skin disease virus (LSDV) belongs to the genus Capripoxvirus from the family Poxviridae and is the causative agent of transmissible disease of cattle with significant economic consequences (Mishchenko et al., 2017; Semakina et al., 2017). The disease is characterized by large skin nodules covering the entire body of the animal, exhaustion, poor milk production, and abortions. Degree of manifestation of clinical symptoms varies from acute to subclinical forms. Due to the huge economic impact on the global cattle industry, the World Organisation for Animal Health (OIE) has classified LSD as a notifiable disease. LSD is a vector-borne disease that is transmitted through bloodsucking arthropods, such as Aedes aegypti (Diptera: Culicidae). Direct and indirect contact between infected and susceptible animals is not considered as way of virus transmission (Mishchenko et al., 2017). The virus can infect other small ruminants, such as sheep and goats, but does not cause clinical diseases (Balinsky et al., 2008; Tuppurainen et al., 2017). However, contact of cattle herds with sheep and goats in pasture/watering areas is considered a potential risk factor for mechanical transmission of LSD (Chihota et al., 2001; Kitching and Mellor, 1986).

History of virus distribution. LSD was first found in Northern Zambia in 1929 (Kumar, 2011). In the 1940s, the disease distributed quickly among cattle in other countries of southern Africa. In 1989, the transcontinental spreading of LSD from African and Asian countries to European countries was first confirmed when the disease was reported in Israel. In the same year, suspicions for LSD cases in a herd of Arabian oryx (Oryx leucoryx) were also recorded in Saudi Arabia (Greth et al., 1992). The disease was imported into Egypt with cattle imported from Africa and kept in a local quarantine station. In the summer of 1988, the virus distributed locally, but before that there were no signs of a clinical disease. This epizootic showed a low morbidity rate (2\%) due to the vaccination, which included almost two million head of cattle with a vaccine against smallpox sheep. On the new outbreaks have also been reported in Kuwait, Bahrain, Yemen, the United Arab Emirates, and Sudan (Tuppurainen and Oura, 2012; Vorster and Mapham, 2008). Between 2012 and 2013, LSD were first registered in Greece, Bulgaria, and Turkey. In 2014-2015, new cases of LSD were observed in Iran, Azerbaijan, Iraq, Greece, and Cyprus (Semakina et al., 2017; Tuppurainen and Oura, 2012).

Outbreaks of LSD in Azerbaijan. Following the outbreak in neighboring Iran in 2014, monitoring was carried out among livestock in the border areas. Animals having clinical signs consistent with LSD infection were first detected in the Bilasuvar District, and subsequently more cases were detected in the Jalilabad, Ujar, and Agdash districts (Fig. 1). Samples were taken from blood and/or lesions of suspicious infected animals and internal organs of cattle. Using real-time polymerase chain reaction (PCR), the presence of the causative agent was confirmed. From June to November 2014, 2,762 cattles in Azerbaijan had clinical signs and lesions at autopsy, corresponding to LSD. Of the 269 samples tested for LSD virus by PCR, 199 (74\%) were positive. A total of 33 animals died, which amounted to $1.2 \%$ of those who had clinical signs of the disease. Preventive measures were taken for retardation the spread of the disease, including restrictions on animal movement, vector control, and vaccination (Zeynalova et al., 2016).

Epidemiology of the disease. There are large differences in the indicators of morbidity and mortality rates during the outbreak of LSD. These differences depend on the following factors: geographical location, climate, farm management conditions, nutritional status and general condition of the animal, cattle breed, immune status, population levels and distribution of insect vectors in various habitats, viral virulence. 


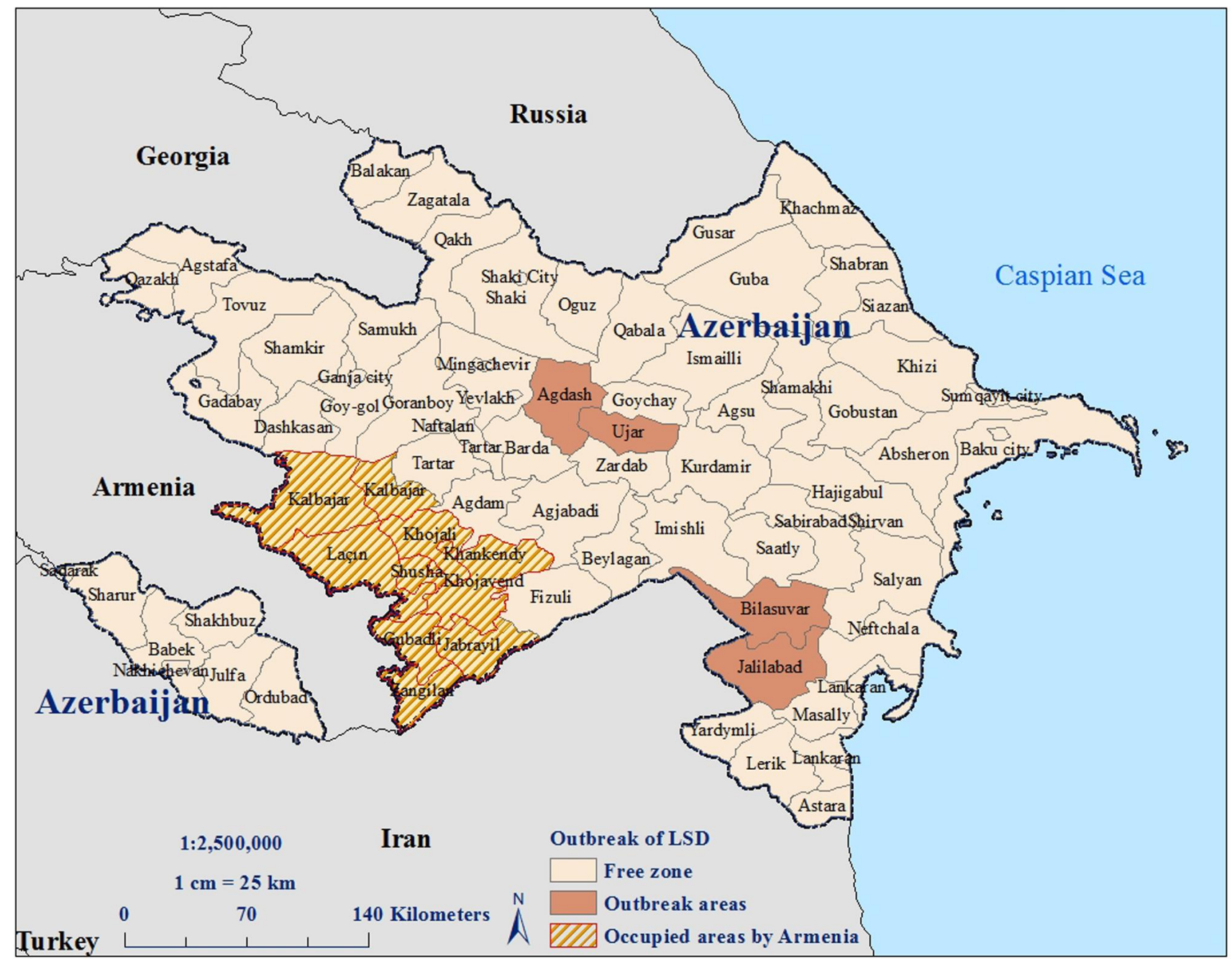

Figure 1. Spread of disease in the Republic of Azerbaijan during 2014 (Zeynalova et. al., 2016)

The morbidity rate of LSD is from 5 to $45 \%$. Higher rates are found in epizootics in South, West and East Africa and Sudan, although so far much lower rates can be observed during one epizootic episode. In addition, high morbidity and mortality rates of $30-45 \%$ and $12 \%$, respectively, were also recorded in Oman in 2009 among the farm livestock population of Holstein breed. LSD has a narrow range of mammalian hosts. Cattle and buffalo are species that become naturally infected during field outbreaks. Five clinical cases of LSD have been reported in Asian water buffalos (Bubalus bubalis) (Semakina et al., 2017; Vorster and Mapham, 2008). Although the virus bears resemblance with sheep pox, other domestic ruminants do not naturally become infected during field outbreaks. All cattle breeds are equally susceptible to this disease. However, some other researchers have found that imported thin-skinned breeds, such as Bos taurus, cattle of Friesland and the Channel Islands, were much more susceptible than native thicker-skinned breeds such as African breeds. Young calves are more susceptible to the disease and can develop a characteristic lesion within 2448 hours, although all age groups of animals are susceptible.
A severe form of the disease develops when a secondary (bacterial) infection is stratified and is characterized by damage of the oral cavity, respiratory and digestive organs. In sick animals, prolonged fever, depression, and a decrease in appetite are noted. Intradermal nodules with a flat surface (diameter $5-50 \mathrm{~mm}$ ) are formed throughout the body of the animal, on the limbs and abdomen, the number of nodules varies from 1-10 to several hundred (Fig. 2). In 1-3 weeks, after the appearance of the tubercles, the necrotic tissue falls away (Chernykh et al., 2017).

Unsequestrated nodules are hardened and remain for a long time. Often, the disease is complicated by a secondary bacterial infection, while edema appears in the deeper layers of the skin and subcutaneous tissue. In lactating cows, the udder is affected, and sometimes it falls away. The temperature of infected animals rises to $40.0-41.5^{\circ} \mathrm{C}$, which can persist for $6-72$ hours or more and rarely can reach 10 days. Infected animals also have lacrimation, increased secretion of the nose and throat, anorexia, general depression and reluctance to move. Fallen animals exhibit signs of enteritis and hemorrhage on the intestinal mucosa, most often the small intestines. 
Joint injuries and edema of the dewlap are recorded in individual animals. Under a visceral pleura the hemorrhage with a diameter of up to $1 \mathrm{~cm}$, sometimes the same hemorrhages are found on the nasal turbinate, in the capsule of the spleen, liver, and in the mucous membrane of the rumen. Sometimes nodular lesions are found in the

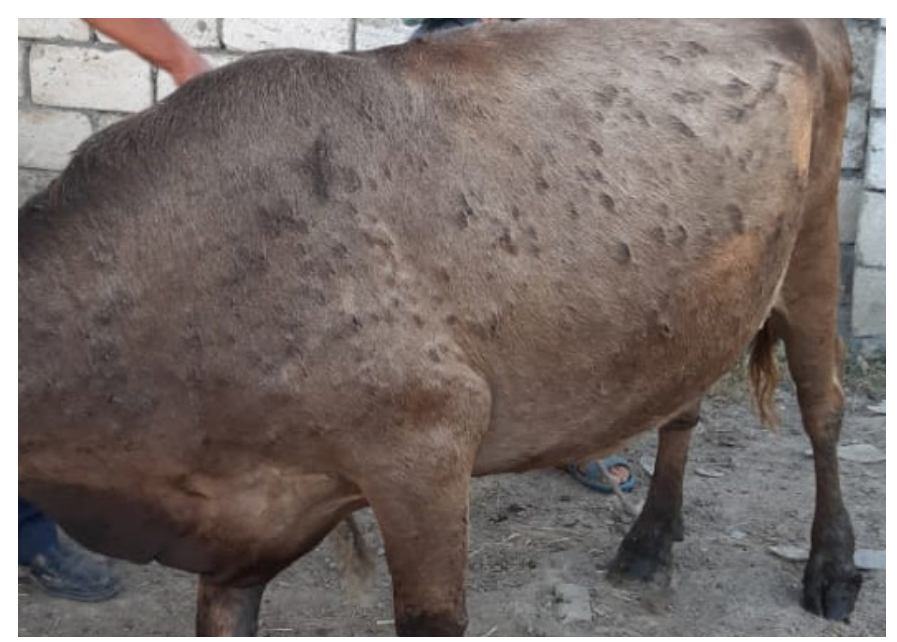

Figure 2. Clinical picture of LSD in cattle

Diagnosis. Laboratory studies and identification of virus are carried out in accordance with OIE Terrestrial Manual (OIE, 2018).

Samples for virus isolation should be collected within the first week after the onset of clinical signs, before the production of neutralizing antibodies. A skin biopsy of early lesions (those where necrosis did not occur) gives samples that can be used to identify the virus by PCR (Orlova et al., 2006). Using this method, it is possible not only to identify the genome of the causative agent of LSD in cows, but also to differentiate it from the related viruses of sheep pox and goat pox. Electron microscopy is an express method for detecting the virus and its differentiation from other pathogens. LSD virus grows in tissue culture of bovine and sheep origin. In retrospective diagnosis for determination of antibodies to LSDV the neutralization reaction is used, which is the most specific serological test, but the test is not sensitive enough to identify animals that have been in contact with the virus and which have developed low levels of neutralizing antibodies (Balinsky et al., 2008; Zeynalova et al., 2016).

Control. LSD control with the help of quarantine and control over the movement is not very effective, as biting flies and some types of insects are the most important method of transmitting the disease. In prevention the spreading of LSD, using of insecticides with repellents can lungs. Typical round necrotic lesions can also be seen on the muzzle, nasal cavity, larynx, trachea, bronchi, inside the lips, gums, dental pillow, anterior abdomen, abomasum, uterus, vagina, nipples, udder, and testicles (Chernykh et al., 2017; Chevelev, 1984; Abutarbush et al., 2015; Tuppurainen and Oura, 2012).

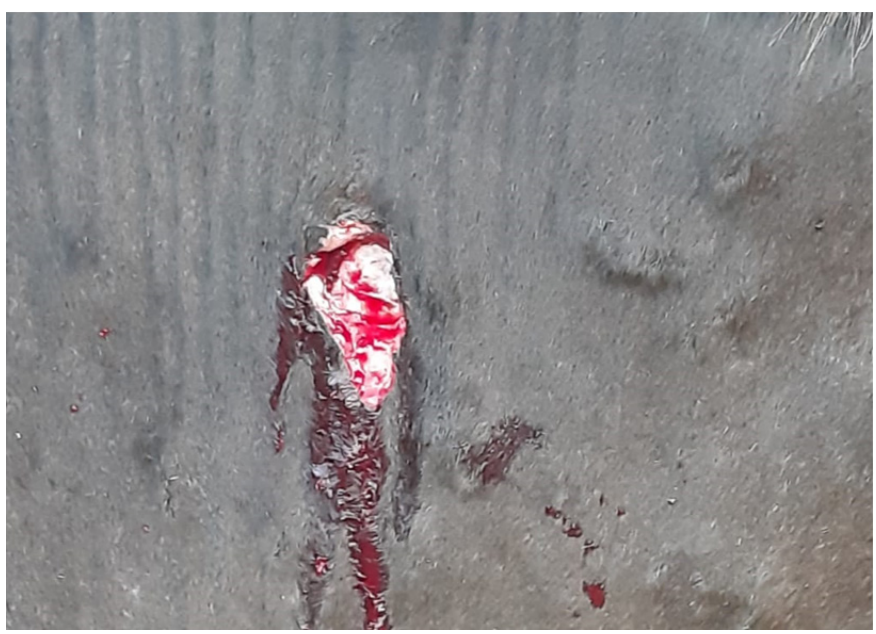

help in prevention the spread of the virus. Outbreaks can be eliminated by means of quarantine, depopulation of infected and affected animals, proper disposal of carcasses, cleaning and disinfection of premises, and insect control. Control can be through vaccination or immunoprophylaxis (Chernykh et al., 2016; Krivonos et al., 2017). In turn, live vaccines, help to control disease in endemic areas.

The following vaccines have been developed:

(1) Homologous live attenuated viral vaccine (Neethling strain: immunity granted lasts up to 3 years);

(2) Heterologous live attenuated viral vaccine (vaccine against sheep pox or goat pox, but can cause local, sometimes severe, reactions). This vaccine is not recommended in countries, free of sheep pox and goat pox, so long as otherwise live vaccines could be a source of infection for susceptible sheep and goat populations;

(3) New generation recombinant vaccines are not commercially available.

Conclusion. The analysis of the literature on LSD shows that many issues remain unstudied and require appropriate research to be carried out. In connection with the difficult epizootic situation and the threat of further spread of the virus, the urgent task is the study of biological properties of the causative agent with a view of development the specific prophylactic agents that would allow to prevent the spread of infection in a short time.

\section{References}

Abutarbush, S. M., $\quad$ Ababneh, M. M., Al Zoubi, I. G., Al Sheyab, O. M., Al Zoubi, M. G., Alekish, M. O. and Al Gharabat, R. J. (2015) 'Lumpy skin disease in Jordan: Disease emergence, clinical signs, complications and preliminaryassociated economic losses', Transboundary and Emerging Diseases, 62(5), pp. 549-554. doi: 10.1111/tbed.12177. 
Balinsky, C. A., ～Delhon, G., Smoliga, G., $\quad$ Prarat, M., French, R. A., Geary, S. J., Rock, D. L. and Rodriguez, L. L. (2008) 'Rapid preclinical detection of sheeppox virus by a realtime PCR assay', Journal of Clinical Microbiology, 46(2), pp. 438-442. doi: 10.1128/JCM.01953-07.

Chernykh, O. Yu., Mishchenko, A. V., Mishchenko, V. A. and Shevkoplyas, V. N. (2016) 'Specific prevention of Lumpy skin disease in cattle' [Spetsificheskaya profilaktika nodulyarnogo dermatita krupnogo rogatogo skota], Kuban Veterinary [Veterinaria Kubani], 3, pp. 3-5. Available at: https://elibrary.ru/item.asp?id=26486598. [in Russian].

Chernykh, O. Yu., Mishchenko, A. V., Mishchenko, V. A., Gubeeva, E. G., Papunidi, K. Kh., Chernov, A. N., Lysenko, A. A., Shevchenko, A. A., Shevkoplyas, V. N. and Vatsaev, Sh. V. (2017) 'Pathomorphological changes in case of Lumpy skin disease in cattle' [Patomorfologicheskie izmeneniya pri nodulyarnom dermatite krupnogo rogatogo skota], Kuban Veterinary [Veterinaria Kubani], 3, pp. 3-9. Available at: https://elibrary.ru/ item.asp?id=29876243. [in Russian].

Chevelev, S. F. (1984) 'Lumpy skin disease' [Nodulyarnyy dermatit], in Arkhipov, N. I. (ed.) Post-Mortem Diagnosis of Animal Viral Diseases [Patologoanatomicheskaya diagnostika virusnykh bolezney zhivotnykh]. Moscow: Kolos, pp. 69-72. [in Russian].

Chihota, C. M., Rennie, L. F., Kitching, R. P. and Mellor, P. S. (2001) 'Mechanical transmission of Lumpy skin disease virus by Aedes aegypti (Diptera: Culicidae)', Epidemiology and Infection, 126(2), pp. 317-321. doi: 10.1017/S0950268801005179.

Greth, A., Gourreau, J. M., Vassart, M., Nguyen-Ba-Vy, Wyers, M. and Lefevre, P. C. (1992) 'Capripoxvirus disease in an Arabian oryx (Oryx leucoryx) from Saudi Arabia', Journal of Wildlife Diseases, 28(2), pp. 295-300. doi: 10.7589/0090-355828.2.295.

Kitching, R. P. and Mellor, P. S. (1986) 'Insect transmission of Capripoxvirus', Research in Veterinary Science, 40(2), pp. 255-258. doi: 10.1016/S0034-5288(18)30523-X.

Krivonos, R. A., $\quad$ Dzhailidi, G. A., Mishchenko, A. V., Mishchenko, V. A., Chernykh, O. Yu., Shevkoplyas, V. N., Dresvyannikova, S. G., Kolomiets, D. V. and Tikhonov, S. V. (2017) 'The problem of prevention and elimination of Lumpy skin disease foci in cattle' [Problema profilaktiki i likvidatsii ochagov nodulyarnogo dermatita krupnogo rogatogo skota], Veterinary Science Today [Veterinariya segodnya], 1, pp. 38-44. Available at: https://elibrary.ru/item.asp?id=29274838. [in Russian].
Kumar, S. M. (2011) 'An outbreak of Lumpy skin disease in a Holstein dairy herd in Oman: A clinical report', Asian Journal of Animal and Veterinary Advances, 6(8), pp. 851-859. doi: 10.3923/ajava.2011.851.859.

Mishchenko, A. V., Mishchenko, V. A., Shevkoplyas, V. N., Krivonos, R. A., Chernykh, O. Yu., Koshchaev, A. G., Lysenko, A. A., Shevchenko, A. A., Konovalov, M. G. and Vatsaev, Sh. V. (2017) 'Ecological features of Lumpy skin disease in cattle' [Ekologicheskie osobennosti nodulyarnogo dermatita krupnogo rogatogo skota], Kuban Veterinary [Veterinaria Kubani], 5, pp. 3-7. Available at: https://elibrary.ru/item.asp?id= 30507854. [in Russian].

OIE (World Organisation for Animal Health) (2018) 'Chapter 3.4.12. Lumpy skin disease', in Manual of Diagnostic Tests and Vaccines for Terrestrial Animals (Mammals, Birds and Bees). $8^{\text {th }}$ ed. Paris: OIE, pp. 1158-1171. Available at: https:// www.oie.int/fileadmin/Home/eng/Health_standards/tahm/3.0 4.12_LSD.pdf.

Orlova, E. S., Shcherbakov, A. V., Diev, V. I. and Zakharov, V. M. (2006) 'Differentiation of Capripoxvirus species and strains by polymerase chain reaction', Molecular Biology, 40(1), pp. 139-145. doi: 10.1134/S0026893306010183.

Semakina, V. P., Zhiltsova, M. V., Savvin, A. V. and Akimova, T. P. (2017) 'Occurrence of Lumpy skin disease in cattle in the world', Veterinary Science Today [Veterinariya segodnya], 3, pp. 13-23. Available at: https://elibrary.ru/item.asp ?id=30079574.

Tuppurainen, E. S. M. and Oura, C. A. L. (2012) 'Review: Lumpy skin disease: An emerging threat to Europe, the Middle East and Asia: Emerging Lumpy skin disease', Transboundary and Emerging Diseases, 59(1), pp.40-48. doi: 10.1111/j.18651682.2011.01242.x.

Tuppurainen, E. S. M., Venter, E. H., Shisler, J. L., Gari, G., Mekonnen, G. A., Juleff, N., Lyons, N. A., De Clercq, K., Upton, C., Bowden, T. R., Babiuk, S. and Babiuk, L. A. (2017) 'Review: Capripoxvirus diseases: Current status and opportunities for control', Transboundary and Emerging Diseases, 64(3), pp. 729-745. doi: 10.1111/tbed.12444.

Vorster, J.H. and Mapham, P. H. (2008) 'Lumpy skin disease', Livestock Health and Production Review, 10(1), pp. 16-21.

Zeynalova, S., Asadov, K., Guliyev, F., Vatani, M. and Aliyev, V. (2016) 'Epizootology and molecular diagnosis of Lumpy skin disease among livestock in Azerbaijan', Frontiers in Microbiology, 7, p. 1022. doi: 10.3389/fmicb.2016.01022. 